\title{
ANALYSIS OF THE TECHNACAL CHARACTERISTICS OF PACSCAT
}

\section{АНАЛІЗ ТЕХНІЧНИХ ХАРАКТЕРИСТИК СУДЕН ТИПУ РАСАСАТ}

\author{
Tetiana V. Tomashevska \\ tatiana.tomashevskaia@nuos.edu.ua \\ ORCID: 0000-0002-3863-4477
}

\author{
Т. В. Томашевська, \\ аспірант, \\ провідний інженер-конструктор ДП «ДПЦК»
}

\author{
Admiral Makarov National University of Shipbuilding, Mykolaiv \\ Національний університет кораблебудування імені адмірала Макарова, м. Миколаӥв
}

\begin{abstract}
Ukraine has favorable conditions for the development of maritime activities. On the Black Sea coast and the Azov Sea coast, there is a sea trade port, a shipbuilding factories and shipyards, a shipbuilding machine, a marine equipment and electrical installation, scientific and scientific research design bureau. In turn, the Ukrainian Navy should be ready to provide humanitarian assistance in the event of natural disaster, man-made disasters or sabotage, in cooperation with other departments of state and non-state organizations. Vision of the ship composition of the Ukrainian Navy of the 2035 (according to the Strategy of Ukrainian Navy) is a modern high-tech Navy that is able to protect the national interest of Ukraine at sea by defending the territory of control of the exclusive economic zone and ensuring the safety of maritime transport. Priority will be given to overwater forces, which will perform tasks on antisubmarine, anti-aircraft, mine barriers and mine neutralization, electronic warfare, naval landing operations.

The idea of creation the project with universal platforms is an attempt to bring the capabilities of the Navy to a new technical level and provide work for the shipbuilding and related industries in Ukraine.

At the boundaries of the article the materials were analyzed, evidently at the available sources, linked to the peculiarities of the design of ships of the PACSCAT type. The basic technical characteristics of ships of the PACSCAT type have been introduced and statistical diagrams have been adopted, based on these projects, which have been prompted for the entire history of this type of vessel.

Indicated the disadvantages and advantages of PACSCAT, in particular from the point of view of its use for military purpose. Based on the results of the study, conclusions were drawn regarding the appropriateness using the type of PACSCAT to create a universal platform in order to meet the needs of Ukrainian Navy.
\end{abstract}

Key words: PACSCAT; performance characteristics; air cushion; skegs; lifting complex.

Анотація. Україна має сприятливі умови для розвитку морської діяльності. На узбережжі Чорного та Азовського морів функціонують морські торговельні порти, суднобудівні заводи та верфі, підприємства корабельного (суднового) машинобудування, морського приладобудування та електромонтажу, науково-дослідні інститути й конструкторські бюро. У свою чергу ВМС ЗС мають бути готовими до надання гуманітарної допомоги у випадку стихійних лих, техногенних катастроф або диверсій у взаємодії з іншими відомствами, державними й недержавними організаціями. Баченням корабельного складу ВМС ЗС України 2035 року (згідно зі Стратегією ВМС України) $\epsilon$ сучасні, високотехнологічні ВМС, які спроможні захистити національні інтереси України на морі шляхом оборони територій, контролю виключної економічної зони та забезпечення безпеки морських перевезень. Пріоритет розвитку надаватиметься надводним силам, які виконуватимуть завдання з протичовнової, протиповітряної постановки мінних загороджень та нейтралізації мін, радіоелектронної боротьби, морських десантних операцій.

Ідея створити проєкт універсальної платформи $є$ спробою вивести на новий технічний рівень можливості ВМС ЗС України та забезпечити роботою суднобудівну та суміжні з нею галузі України.

У межах статті проаналізовано матеріали, наявні в доступних джерелах, пов'язані з особливостями проєктування суден типу PACSCAT. Наведено основні технічні характеристики суден та кораблів типу РACSCAT й отримано статистичні діаграми, засновані на даних проєктів, які були побудовані за всю історію створення суден та кораблів такого типу.

Вказано на недоліки та переваги суден типу PACSCAT, зокрема, з точки зору застосування його за військовим призначенням.

За результатами дослідження зроблено висновки щодо доцільності використання типу PACSCAT для створення універсальної платформи-носія з метою задоволення потреб ВМС ЗС України.

Ключові слова: РACSCAT; тактико-технічні характеристики; повітряна подушка; скег; підйомний комплекс. 


\section{ПОСТАНОВКА ЗАДАЧІ}

Україна - морська держава, тому захист іiі економічних і національних інтересів, територіальної цілісності та суверенітету держави нерозривно пов'язані з морем. ВМС ЗС України $є$ і будуть основним інструментом захисту держави на морі та 3 морського напрямку.

Створення універсальної платформи для можливості забезпечення національних ВМС катерами різного призначення $\epsilon$ важливою спробою збільшити оборонну здатність на морі та розпочати відродження вітчизняної кораблебудівної галузі. На базі однієї типової «платформи» можна отримати десантний, ракетний катер, катер протимінної оборони, протидиверсійний катер, допоміжне судно і катери прикордонної служби. Модульне виконання «платформи» дозволить мінімізувати витрати на зміну озброєння та залежних від них приміщень, що значно знижує вартість створення потрібної модифікації відносно нового проєкту.

Використання легких та міцних матеріалів (композитних та алюміній-магнієвих) дозволить суттєво збільшити долю ваги «корисного навантаження» (спеціалізованого озброєння, розмістити обладнання тощо).

Крім того, дуже важливим $є$ те, що у створенні такої багатоцільової платформи будуть задіяні тільки українські підприємства.

Тому створення досконалого проєкту може не тільки забезпечити ВМС України ефективними знаряддями виконання їхніх задач, а й вийти на світовий ринок судно- та кораблебудування з конкурентоспроможною пропозицією.

\section{АНАЛІЗ ОСТАННІХ ДОСЛІДЖЕНЬ І ПУБЛІКАЦІЙ}

Здебільшого наукові джерела, пов'язані з теорією проєктування таких типів суден, залишились датованими 1960-1990-ми роками, коли радянська та світова наука приділяла багато уваги суднам 3 динамічними принципами підтримання. Доступними сучасними дослідженнями в цій галузі $є$ наукові праці російських учених, які продовжують напрацювання вчених 3 колишнього СРСР, а також дослідження китайських і частково європейських та американських учених. Ці праці - дослідження конкретних проєктів за певними напрямами, наприклад, дослідження хитавиці на регулярному хвилюванні [1], дослідження гідродинамічних характеристик [2; 3], експериментальні дослідження ходовості [4], морехідності [5]. Серед українських дослідників насамперед слід відзначити інститут гідромеханіки НАН України, який має ряд напрацювань 3 дослідження буксирувального опору моделі PACSCAT [6]. Є праці більш загального характеру, пов'язані 3 розробкою методик проєктування таких типів суден та визначень їхніх раціональних технічних параметрів [7; 8].

\section{ВІДОКРЕМЛЕННЯ НЕ ВИРІШЕНИХ} РАНІШЕ ЧАСТИН ЗАГАЛЬНОӤ ПРОБЛЕМИ

Але, проаналізувавши доступні публікації, можна зробити висновок, що дуже багато питань залишається недослідженими або малодослідженими, а саме спостерігається певний дефіцит інформації сучасного підходу до концептуального проєктування та вироблення методики оптимізації характеристик PACSCAT.

\section{МЕТА ДОСЛІДЖЕННЯ}

Метою дослідження є синтез та аналіз матеріалів, пов'язаних з проєктуванням та побудовою суден типу PACSCAT.

\section{ОСНОВНИЙ МАТЕРІАЛ}

Однією з головних задач, які ставили перед собою суднобудівники протягом століть, є зниження опору води та підвищення швидкості, тому ідея підняти судно $з$ води в повітря була дуже звабливою для проєктантів суден ще з XVIII століття.

Перші у світі експериментальні катери на повітряній подушці скегового типу були побудовані у 1934-1939 році радянським конструктором Володимиром Левковим, метою робіт якого було створення надшвидких катерів для військового застосування. У розробленні скегових суден на повітряній подушці (далі - СППС) завдяки величезній напрацьованій базі проєктів радянських учених лідерство мають російські конструкторські бюро. Це насамперед ЦМКБ «Алмаз» - найбільший виробник проєктів СППС для військового застосування.

На Заході монополістом у галузі створення та будування СППС є Норвегія. Суднобудівна норвезька компанія Umoe Mandal спеціалізується на швидкісних багатоцільових катерах, тральщиках та ракетних кораблях. Велика Британія також має своїх спеціалістів у проєктуванні та виробництві СППС. Давно займаються багатокорпусними суднами США. Маючи велику кількість дослідних гідродинамічних лабораторій, вони експериментують 3 формами корпусу та принципами підтримання.

Вітчизняному визначенню скегового катамарану на ПП відповідає інтернаціональне - PACSCAT Partial Air Cushion Support CATamaran.

Натепер досвід побудови РACSCAT має вісім країн (рис. 1). Розподілення кількості PACSCAT за призначенням відображено на рис. 2.

У таблиці 1 наведено перелік деяких проєктів типу PACSCAT та їхні основні характеристики.

\section{Особливості просктування PACSCAT}

PACSCAT як система складається 3 двох основних складників: основний корпус і підйомний комплекс (далі - ПК). Функцією ПК та скегів 


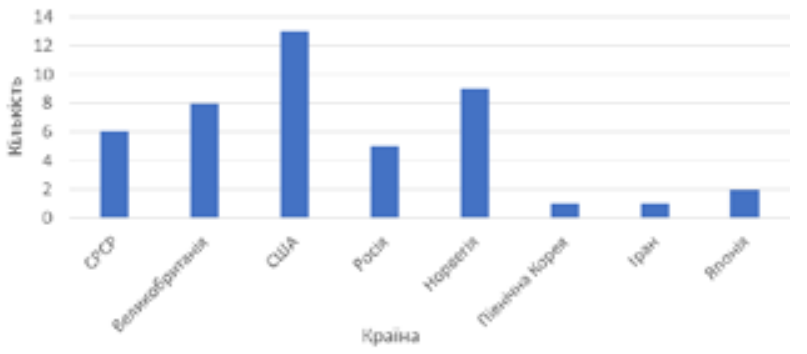

Рис. 1. Розподілення кількості РACSCAT за країнами походження

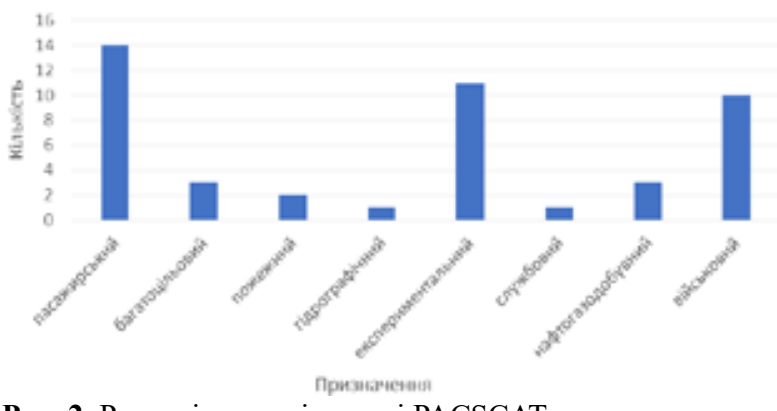

Рис. 2. Розподілення кількості РАCSCAT за призначенням

Таблиця 1. Основні технічні характеристики деяких проектів типу PACSCAT

\begin{tabular}{|c|c|c|c|c|c|c|c|c|c|}
\hline & «Чайка» & «Сивуч» & $\begin{array}{l}\text { WAVE- } \\
\text { CRAFT }\end{array}$ & SKJOLD & Oksoy & ISDC & Hisho & HLALC & «Богомол» \\
\hline 1 & 2 & 3 & 4 & 5 & 6 & 7 & 8 & 9 & 10 \\
\hline Країна & СРСР & Росія & Норвегія & Норвегія & Норвегія & $\begin{array}{l}\text { Велико- } \\
\text { британія } \\
\end{array}$ & Японія & США & Україна \\
\hline Призначення & цивільне & військове & цивільне & військове & військове & військове & цивільне & військове & військове \\
\hline Проєкт & 1879 & 1239 & \begin{tabular}{|c|} 
Commander \\
27 \\
\end{tabular} & - & - & - & - & - & 58208 \\
\hline Рік побудови & 1976 & $\begin{array}{c}1984- \\
1999 \\
\end{array}$ & 2000-ні & 1999 & $\begin{array}{c}1990- \\
1995\end{array}$ & 2007 & 1989-1995 & проєкт & проєкт \\
\hline \multicolumn{10}{|l|}{$\begin{array}{l}\text { Габаритні } \\
\text { розміри, м }\end{array}$} \\
\hline довжина & 26,4 & 64 & 26,6 & 46,8 & 55,2 & 30,0 & 70,0 & 67,3 & 33 \\
\hline ширина & 7,1 & 17,2 & 10,4 & 13,5 & 13,6 & 7,7 & 18,6 & 15 & 12 \\
\hline \multicolumn{10}{|l|}{ осадка } \\
\hline $\begin{array}{l}\text { У водотоннажно- } \\
\text { му режимі }\end{array}$ & 1,23 & 3,8 & 3,0 & 2,3 & 2,5 & - & 3,5 & - & 1,4 \\
\hline на ПП & 0,7 & 1,0 & 0,8 & 0,8 & 0,84 & - & 1,1 & 2,1 & 0,9 \\
\hline $\begin{array}{l}\text { Водотоннажність } \\
\text { повна, т }\end{array}$ & 47,5 & 1000 & 15 (DW) & 260 & 375 & 175 & 200 (DW) & 1566 & 145 \\
\hline \multicolumn{10}{|l|}{ Швидкість, вузли } \\
\hline на ПП & 23 & 55 & 42 & 60 & 30 & - & 50 & 25 & $\begin{array}{c}\text { не менше } \\
50 \\
\end{array}$ \\
\hline без ПП & - & $18-20$ & - & - & - & - & - & - & $30-35$ \\
\hline $\begin{array}{l}\text { Дальність плаван- } \\
\text { ня, милі }\end{array}$ & 180 & 2500 & 600 & 800 & 1500 & - & 500 & 2500 & 600 \\
\hline \multirow[t]{2}{*}{$\begin{array}{l}\text { Морехідність, } \\
\text { бали }\end{array}$} & $\begin{array}{c}\text { До 4-х } \\
\text { (включно) }\end{array}$ & $\begin{array}{c}\text { До 5-ти } \\
\text { (включно) }\end{array}$ & $\begin{array}{c}\text { До 4-х } \\
\text { (включно) }\end{array}$ & $\begin{array}{c}\text { До 6-ти } \\
\text { (включ- } \\
\text { но) } \\
\end{array}$ & - & $\begin{array}{l}2-x(30 \\
\text { вузлів) }\end{array}$ & $\begin{array}{c}\text { До 6-ти } \\
\text { (включно) }\end{array}$ & - & $\begin{array}{c}\text { До 3-х } \\
\text { (включно) }\end{array}$ \\
\hline & «Чайка» & «Сивуч» & $\begin{array}{l}\text { WAVE- } \\
\text { CRAFT }\end{array}$ & SKJOLD & Oksoy & ISDC & Hisho & HLALC & «Богомол» \\
\hline \multicolumn{10}{|l|}{ Головний двигун } \\
\hline Марка & $\begin{array}{c}\text { 3Д12Н- } \\
520\end{array}$ & \begin{tabular}{|c|}
2 ГТУ \\
М10-1 \\
2 дизеля \\
М-511А \\
\end{tabular} & - & $\begin{array}{c}2 \Gamma \mathrm{T} \\
\text { Allison } \\
571-\mathrm{K}\end{array}$ & $\begin{array}{c}\text { MTU } \\
\text { 12V } 396 \\
\text { TE84 }\end{array}$ & MTU & ГТД & $\begin{array}{l}\text { Wartsila } \\
\text { 9L46F }\end{array}$ & UGT3000 \\
\hline $\begin{array}{l}\text { Максимальна } \\
\text { потужність, к.с. }\end{array}$ & $2 \times 520$ & \begin{tabular}{|l|}
$2 \times 18000$ \\
$2 \times 10000$ \\
\end{tabular} & $2 \times 1960$ & $2 \times 8160$ & $2 \times 1850$ & - & $2 \times 15780$ & $2 \times 14690$ & $2 \times 4760$ \\
\hline \multicolumn{10}{|l|}{ Рушій } \\
\hline Тип & Водомет & $\begin{array}{c}\text { Гвинти- } \\
\text { тандем } \\
\text { в опуск- } \\
\text { них } \\
\text { колонках }\end{array}$ & Водомет & Водомет & Водомет & Водомет & Водомет & Водомет & Водомет \\
\hline Кількість & 2 & $2 \times 2$ & 2 & 2 & 2 & 2 & 2 & 2 & 2 \\
\hline
\end{tabular}


Продовження таблиці 1

\begin{tabular}{|l|c|c|c|c|c|c|c|c|c|}
\hline \multicolumn{1}{|c|}{1} & 2 & 3 & 4 & 5 & 6 & 7 & 8 & 9 & 10 \\
\hline $\begin{array}{l}\text { Допоміжний } \\
\text { двигун (для ство- } \\
\text { рення ПП) }\end{array}$ & & & & & & & & \\
\hline Тип & $\begin{array}{c}\text { ПД6С- } \\
150 \mathrm{~A}\end{array}$ & $\mathrm{M-503Б}$ & & MTU 183 & $\begin{array}{c}\text { MTU 8V } \\
396 \text { TE54 }\end{array}$ & - & ГТД, ДД & $\begin{array}{c}\text { Caterpillar } \\
3516\end{array}$ & - \\
\hline Потужність, к.с. & АМг & АМг & $\begin{array}{c}\text { композит- } \\
\text { ний }\end{array}$ & $\begin{array}{c}\text { компо- } \\
\text { зитний }\end{array}$ & $\begin{array}{c}\text { склопла- } \\
\text { стик }\end{array}$ & АМг & АМг & сталь & АМг \\
\hline Матеріал корпусу & АМр & $2 \times 490$ & $2 \times 816$ & $2 \times 870$ & - & $\begin{array}{l}1 \times 1,970, \\
3 \times 1,970\end{array}$ & $2 \times 2230$ & - \\
\hline
\end{tabular}

$\epsilon$ підтримання основного корпусу на достатньому віддаленні від поверхні моря, але цю задачу вони вирішують різними способами. ПК утворює під'ємну силу дією статичного тиску повітря на днищеву частину основного корпусу, розташовану між скегами, скеги ж утворюють гідростатичну, а в ряді випадків і гідродинамічну підйомну силу під час взаємодії свого об’єму та форми з поверхнею води. Однак не менш важливою функцією скегів є утримання (разом із гнучким огородженням (ГО) ПК) повітря під днищем судна. Типову схему системи PACSCAT зображено на рис. 3 [1].

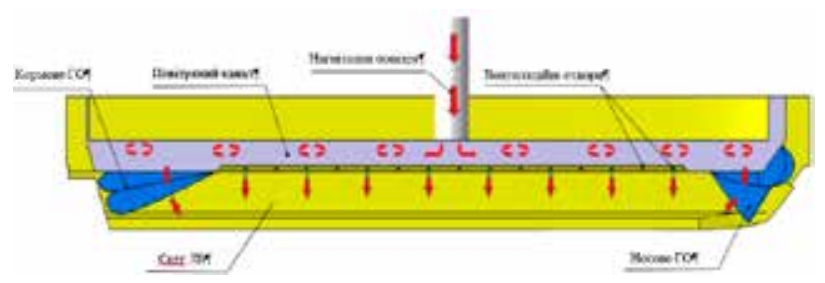

Рис. 3. Схема системи РACSCAT

Номенклатура основних техніко-економічних характеристик (далі - TEX) PACSCAT практично повністю відповідає номенклатурі ТЕХ водотоннажних суден. До основних ТЕХ (для військових кораблів тактико-технічні вимоги) PACSCAT відносяться:

- призначення та задачі, які він повинен вирішувати;

- пасажиромісткість, корисний вантаж чи склад функціонального обладнання;

- водотоннажність (порожнем, стандартна, нормальна, повна та ін.);

- швидкість (повна, економічна, експлуатаційна та ін.);

- дальність плавання;

- автономність (за запасами палива, провізії та ін.);

- морехідні якості (за умовами нормальної експлуатації, за безпекою плавання та ін.);

- комплектація особовим складом;

- габаритні розміри корпусу, скегів;

- склад та потужність головної енергетичної установки (ГЕУ), яка зазвичай складається 3 двигуннорушійного та підйомного комплексів;

- склад та потужність електроенергетичної системи;
- маса палива (нормальний запас, у перевантаженні та ін.);

- конструктивні особливості основних підсистем (гнучких огороджень ПП, рушіїв, нагнітачів тощо).

Початковим етапом проєктування $є$ визначення району експлуатації та призначення судна, що дозволяє висунути специфічні вимоги до нього (морехідність, осадка, вартість побудови та експлуатації, коефіцієнт утилізації тощо). 3 аналізу умов експлуатації можна отримати орієнтовні значення, що характеризують ступінь напруженості використання технічних засобів та спектр режимів експлуатації ГЕУ, ресурсні характеристики суднових підсистем, визначити кількість та вартість обладнання, що замінюється в процесі експлуатації судна, а також вартість експлуатації (для військових - вартість життєвого циклу).

\section{Форма та розміри корпусу}

Корпус PACSCAT складається з основної частини (основного корпусу), яка зазвичай має близьку до паралелепіпеду форму (за виключенням носової частини), та бортових частин, які виходять $з$ основного корпусу вниз, - скегів, ширина яких менше половини ширини основного корпусу. Саме сполучення основного корпусу та бортових скегів і утворює форму, подібну до катамарану (рис. 4).

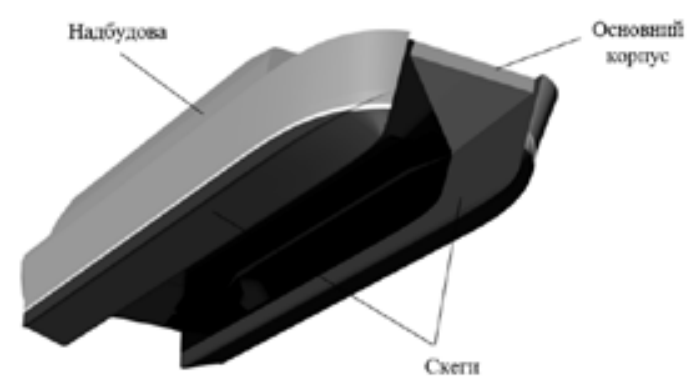

Рис. 4. Основні частини корпусу PACSCAT

Основний корпус забезпечує загальну та місцеву міцність, плавучість, непотоплюваність та служить об'ємом для розміщення всіх підсистем та необхідного обладнання. Особливість форми основного корпусу дозволяе максимально раціонально використовувати його об'єм. 


\section{СУДНОБУДУВАННЯ № 3-2021}

Скеги - багатофункціональні елементи корпусу PACSCAT (забезпечення остійності та непотоплюваності; участь у забезпеченні загальної та місцевої міцності, а також морехідних якостей (швидкість і плавність хитавиці, зменшення перевантажень тощо); огородження області повітря підвищеного тиску на більшій частині ії периметру; об'єм для розміщення рушіїв, трансмісій енергетичної установки (ЕУ) та інших підсистем; опори при постановці в док тощо). Враховуючи це, на форму та конструкцію скегів у проектуванні PACSCAT звертають виключно велику увагу. У процесі розвитку форма скегів змінювалась зі скругленої форми, яка забезпечувала остійність в умовах відриву скегів від поверхні води, до складної форми зі скулами та реданами. На рис. 5 і рис. 6 наведено форми скегів першого та другого типів відповідно [10].
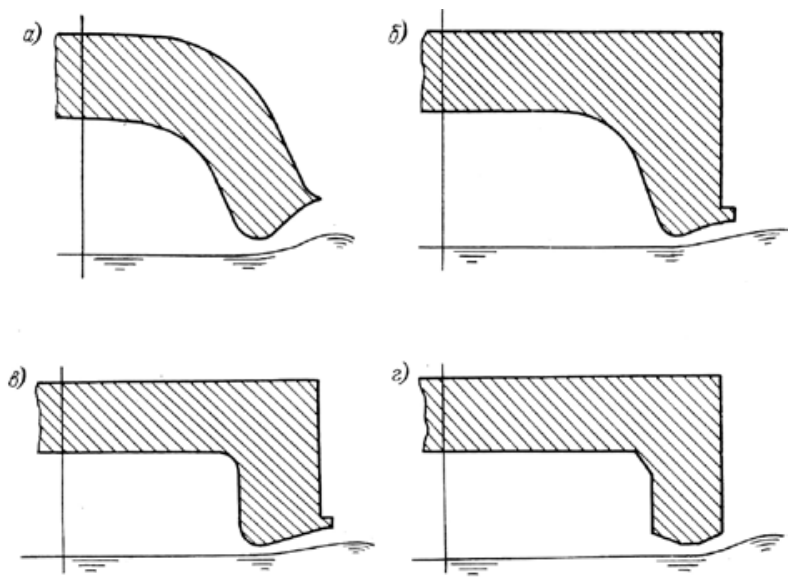

Рис. 5. Форма скегів для СППС першого типу (з відривом від поверхні води)

На форму і конструкцію кормової частини скегів упливає прийнятий під час проєктування тип рушіїв та ix розміщення. Наприклад, у випадку використання греб-

них гвинтів та водометних рушіїв, розміщених у нижній частині скегів, останні мають просту транцеву корму.

Наявність під корпусом РACSCAT області повітря підвищеного тиску певних розмірів та відносного подовження ( $\lambda П П=\mathrm{LПП/ВПП),} \mathrm{скегів} \mathrm{та} \mathrm{кінцевих}$ гнучких огороджень ПП, а також аеродинамічні та інші конструктивні особливості, призводять до характерних для PACSCAT головних розмірів та їх співвідношень (табл. 2).

Таблиця 2. Залежність головних розмірів від відносного подовження [9]

\begin{tabular}{|c|c|}
\hline $\begin{array}{c}\text { Відносні подовження } \\
\text { ПП }\end{array}$ & $\begin{array}{c}\text { Відношення довжини } \\
\text { до ширини корпусу }\end{array}$ \\
\hline $1,5 \leq \lambda_{\text {ПП }} \leq 3$ & $1,6 \leq \mathrm{L} / \mathrm{B} \leq 4,5$ \\
\hline $6 \leq \lambda_{\Pi \Pi} \leq 8$ & $5,5 \leq \mathrm{L} / \mathrm{B} \leq 8,5$ \\
\hline
\end{tabular}

Знаючи значення водотоннажності в першому наближенні, можна визначити головні розміри [10]. Відправною точкою для визначення водотоннажності PACSCAT $є$ співвідношення між заданою масою корисного навантаження та статистичними даними про частку цього навантаження в повній водотоннажності судна G. Після оцінювання водотоннажності виникає можливість визначити головні розміри судна, при цьому використовують параметр $p_{\text {пा }} / L_{\text {пा }}$, що характеризує відносні деформації водної поверхні під час поздовжнього руху і пов'язаний з ним хвильовий опір, основне співвідношення розмірів $\lambda П П$, відносну водотоннажність скегів $\gamma \mathrm{Wc \kappa} / \mathrm{G}$ та задану висоту хвилі, яка характеризує морехідність судна.

$$
\begin{gathered}
L_{\Pi \Pi}=\sqrt[3]{\frac{\left(G-\gamma W_{\mathrm{c \kappa}}\right)\left(\frac{L_{\Pi \Pi}}{B_{\Pi \Pi}}\right)}{\frac{p_{\Pi \Pi}}{L_{\Pi \Pi}}} ;} \\
B_{\Pi \Pi}=\frac{L_{\Pi \Pi}}{\frac{L_{\Pi \Pi}}{B_{\Pi \Pi}}} .
\end{gathered}
$$
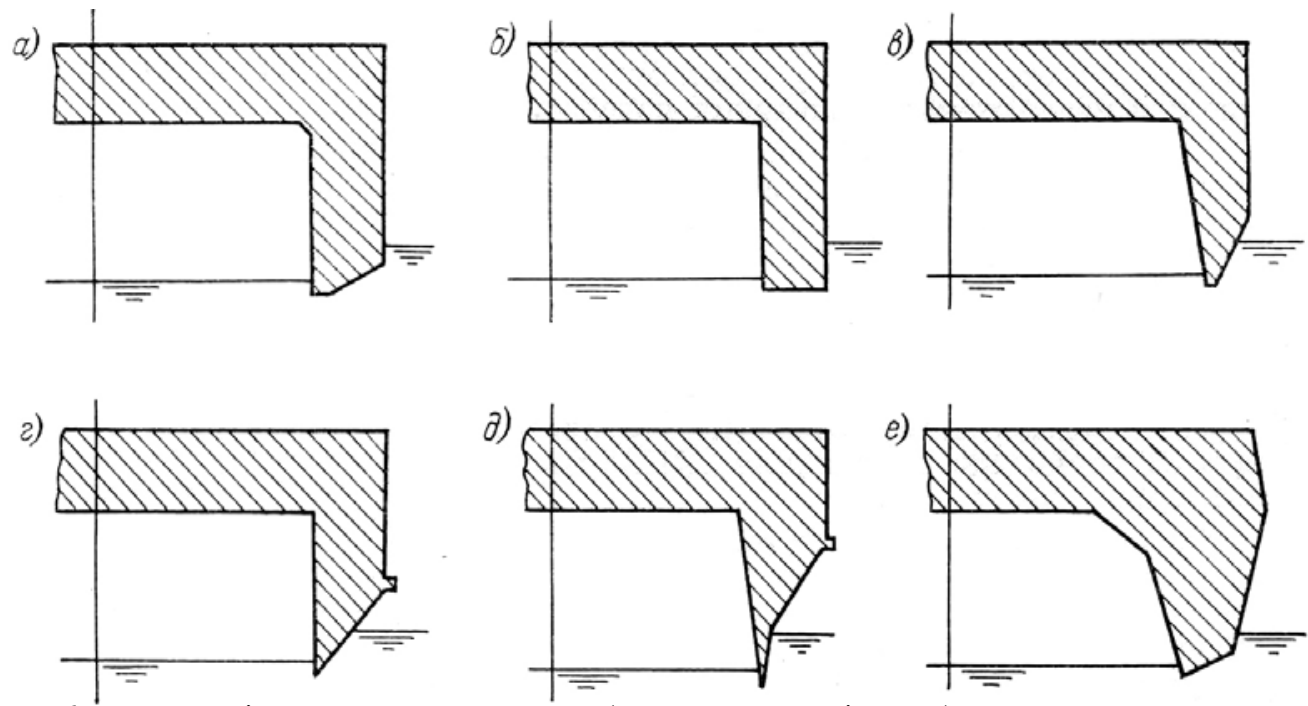

Рис. 6. Форма скегів для СППС другого типу (частково занурені у воду) 


$$
\begin{aligned}
& L=k_{L} L_{\text {пा }} \text {, де } k_{L}=1,10 \div 1,20 \text {. } \\
& B=B_{\text {Пп }}\left[1+2 k_{B}\left(B_{\text {ск }} / B_{\text {Пп }}\right)\right] \text {, де } k_{B}=1,0 \div 2,0 \text {. }
\end{aligned}
$$

Висота скегу визначається за заданою морехідністю судна, а висота борту основного корпусу - на основі об'єму, необхідного для розміщення необхідного обладнання, екіпажу тощо.

Головні розміри, отримані таким чином, служать основою для розроблення теоретичного та конструктивного креслення корпусу, а також для розрахунків його якостей.

Через масу та числа Фруда можна визначити гідродинамічну якість судна (рис. 7) [10].

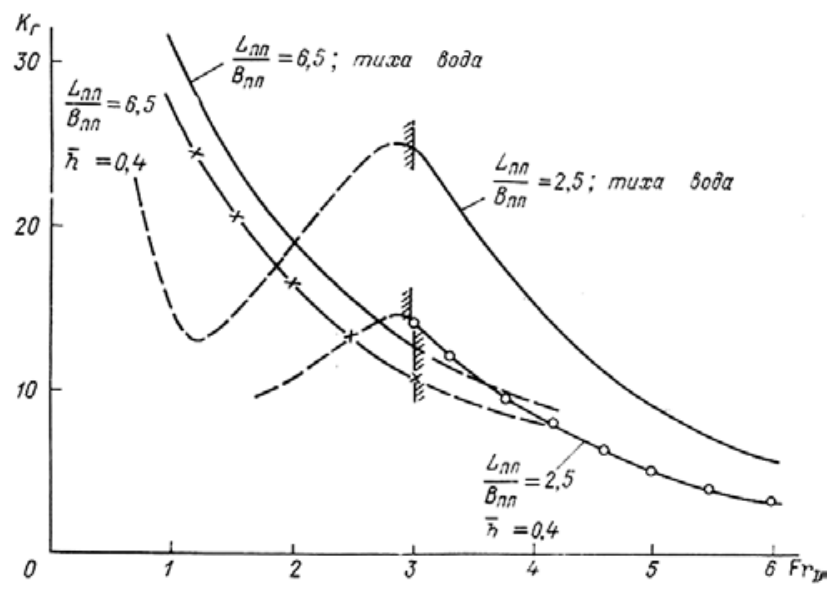

Рис. 7. Залежність гідродинамічної якості РACSCAT від маси та числа Фруда

У питаннях архітектурного та компонувального проектування значну роль відіграють результати аналізу найкращих зразків суден означеного функціонального типу. У першому наближенні границі зміни водотоннажності, головних розмірів та потужності енергетичної установки можуть визначатися на основі аналізу статистичних даних побудованих або спроєктованих суден аналогічного призначення.

\section{Матеріал корпусу}

Під час проектування високошвидкісних суден обгрунтування вибору матеріалу пов'язане 3 необхідністю забезпечення сприятливих конструктивних, технологічних та вартісних показників, а також мінімізації всіх мас. На практиці вибір робиться на зіставленні показників під час використання композиційних матеріалів (КМ), алюмінієвомагнієвих сплавів та сталі. Вибір матеріалу в значній мірі визначається архітектурними задачами при проектуванні, його призначенням та характерними вимогами до міцності.

Для первісної оцінки характеристик маси корпусу та надбудови можна застосовувати методи стандарту ISO 12215-5 [11], який дозволяє оцінити масу та вартість конструкції високошвидкісного судна на ранніх ета- пах проєктування. Більш детальний аналіз характеристик маси та вартості передбачає розрахунок варіантів конструкції за правилами конкретних класифікаційних товариств або прямими інженерними методами. Характеристики мас конструкцій суден залежать від розрахункової швидкості та висоти хвилі, що визначають рівень розрахункових прискорень. Як правило, для відносно невеликих суден головними є розрахунки місцевої міцності (особливо - міцності днища), розрахунки загальної міцності носять перевірочний характер.

Серед числа експлуатаційних факторів, що впливають на вибір матеріалу PACSCAT, необхідно враховувати умови експлуатації, а також зношення в разі висадки на необладнаний берег.

У гонитві за швидкістю та конкурентоспроможністю на сучасному ринку високошвидкісних суден, до яких належить і PACSCAT, відбувається поступовий перехід до заміни металічних конструкцій полімерними КМ, які складаються 3 армуючих та зв'язуючи елементів.

Перспективність застосування полімерних композитних матеріалів у суднобудуванні підтверджується тим, що у світовій практиці ці матеріали знайшли широке розповсюдження і частка їх у будівництві кораблів (суден) продовжує зростати. Ключовими гравцями на ринку композитів є Китай, США, ЄС і країни Південно-Східної Азії. На суднобудування припадає поки всього 2-3\% [12].

Як показує огляд побудованих PACSCAT (рис. 8), найбільш поширеними у 80-90-ті роки були легкосплавні матеріали, але 3 розвитком композиційних матеріалів попит на них у сфері створення високошвидкісних суден, зокрема PACSCAT, став переважним.

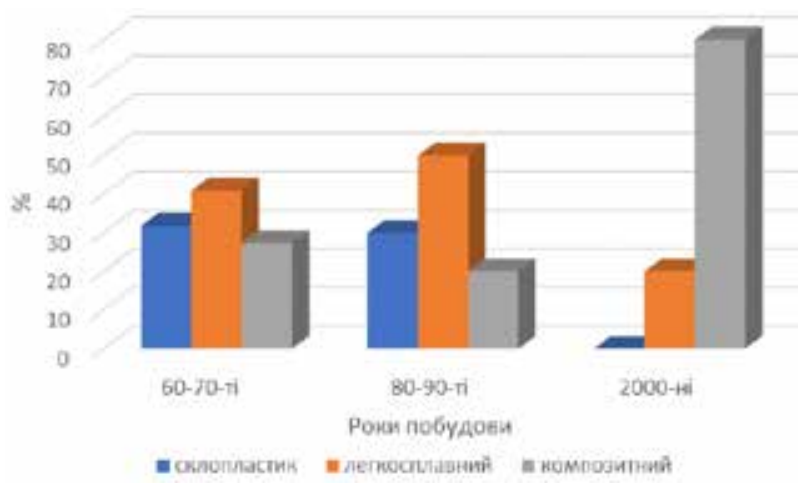

Рис. 8. Розподілення кількості (у відсотках) PACSCAT за матеріалом корпусу

Але виявилося, що нормативно-технічна база для даного типу матеріалу найменше вивчена, відсутні стандарти за системою сертифікації і контролю якості. Багато з них не відповідають сучасному рівню розробок з композитних матеріалів і знаходяться в протиріччі із сучасною методологією проектування і будівництва виробів з них. Нормативнотехнічна база для проектування і будівництва суден 


\section{СУДНОБУДУВАННЯ № 3- 2021}

та кораблів зі сталі, а також алюмінієво-магнієвих сплавів, є в наявності. У вітчизняних підприємств накопичений великий практичний досвід із проектування i будівництва кораблів i катерів iз суднобудівних сталей i алюмінієво-магнієвих сплавів (далі - АМг).

Розглянемо переваги та недоліки основних матеріалів - склопластику $[13 ; 14 ; 15 ; 16]$ та алюмінієвих сплавів [17; 18; 19].

До позитивних властивостей склопластиків відноситься те, що цей матеріал немагнітний, неелектропровідний, радіопрозорий, володіє теплоі звукоізольованими властивостями, водостійкий.

Склопластик має такі хороші експлуатаційні конструктивні якості, як:

- корозійна стійкість;

- стійкість проти гниття і враження морськими шкідниками;

- висока демпфуюча здатність;

- стабільність фізико-механічних властивостей;

- висока питома міцність під час дії статичних і динамічних навантажень;

- здатність ослаблення потоку проникаючої радіації становить 22\% від здатності вуглецевої сталі; піддається дегазації і дезактивації;

- можливість створення матеріалів із заданою анізотропією механічних і фізичних властивостей.

Разом 3 істотними перевагами конструкцій із склопластика необхідно відзначити недоліки цього матеріалу:

- низьку жорсткість;

- відсутність полички плинності, що робить матеріал крихким, руйнування конструкції наступає раптово;

- низьку стійкість до стирання;

- токсичність;

- старіння і зниження характеристик міцності від дії атмосферних умов.

Альтернативним матеріалом для корпусу PACSCAT є AМг. Легкий, міцний і стійкий до корозії алюміній - ідеальний метал для суднобудування. У порівнянні з композитними матеріалами АМг менш чутливі до низьких температур.

АМг широке розповсюдження одержали в кораблебудуванні: швидкохідні патрульні катери, багатофункціональні кораблі прибережної зони. На багатьох кораблях різних класів разом зі сталевим корпусом використовують як матеріал надбудови АМг.

Переваги АМг:

- легкість;

- ударо- і вібростійкість;

- висока ремонтопридатність;

- легкість обробки і зварювання;

- екологічність.

\section{Недоліки АМг:}

- корозія;

- висока вартість матеріалу і робіт.

АМг виправданий, якщо судно експлуатуватиметься у важких умовах - на мілководді, в районах 3 великою кількістю плаваючого сміття, швартування в невпорядкованих місцях, в холодному кліматі й т. п. Скажімо, алюмінієвий корпус може з успіхом зимувати на морозі, тоді як склопластиковий (особливо «сендвіч») або дерево за низьких температур, швидше за все, «порве». Також потрібно врахувати можливості вибраної верфі й доступність матеріалу. Наприклад, будівництво судна $з$ армованих пластиків вимагає підтримку певного мікроклімату у виробничих приміщеннях.

\section{Тип енергетичної установки}

Однією з головних переваг суден типу PACSCAT у порівнянні з водотоннажними суднами $є$ можливість руху 3 високою швидкістю за меншої необхідної потужності. Але це явище спостерігається тільки на відносно високих швидкостях, що пояснюється великими витратами потужності на утворення ПП. Отже, основною відмінністю ЕУ PACSCAT $\epsilon$ наявність підйомної системи - нагнітачів, що забезпечують безперебійне постачання повітря у ПП.

EУ PACSCAT складається 3 таких складових частин:

- головні двигуни;

- рушії;

- підйомна система;

- системи та пристрої, що обслуговують ЕУ.

Тип ЕУ визначається типом головних двигунів. Здебільшого застосовують газотурбінні двигуни (ГТД), дизельні двигуни (ДД), а також їх комбінацію. Наприклад [20], фірмою «Алмаз» для проєкту 1239 у результаті численних варіантів було вибрано комбіновану схему 3 дизельними та газотурбінними двигунами. Унаслідок кораблі проєкту «Сівуч» оздоблюються одразу шістьма двигунами декількох типів. Для економічного ходу корабель має два дизельних двигуна М-511А, два двигуна М-503Б призначені для нагнітання повітря під днище корабля під час руху 3 великою швидкістю, яка забезпечується за допомогою двох ГТД М-10. Як рушії застосовано чотири гребних гвинта, розміщених на спеціальних поворотних колонках у кормовій частині корабля. Під час економічного ходу колонки підіймаються над водою та розташовуються у вертикальному положенні. У випадку переходу на швидкісний режим колонки занурюються у воду та запускаються ГТД. Розробники стверджують, що завдяки такій комбінації ЕУ та оригінальній системі скегів з ГО кораблі цього проєкту мають змогу рухатися на 36-ти режимах, умовно розділених на три групи: режим катамарана та два режими корабля на ПП. За допомогою тільки дизелів М-511А вони здатні рухатись зі швидкістю до 18-20 вузлів. Для розгону до більших швидкостей треба застосовувати нагнітальні дизелі та 
ГТД. У разі включення всієї ЕУ на повну потужність кораблі можуть розганятися до швидкості 55 вузлів, але при цьому дальність плавання скорочується більше ніж у три рази в порівнянні 3 економічним ходом. Цікаво те, що серед цих 36-ти режимів роботи двигунів, гвинтів та скегового корпусу є такий, який дозволяє кораблю рухатись тільки за допомогою нагнітачів. У разі закритого переднього та відкритого заднього ГО ПП рухається тільки за рахунок витікання повітря, яке нагнітається під днище. Корабель у цьому режимі може рухатись зі швидкістю до трьох вузлів, навіть проти вітру.

Загальна статистика застосування типів ЕУ зображена на рис. 9.

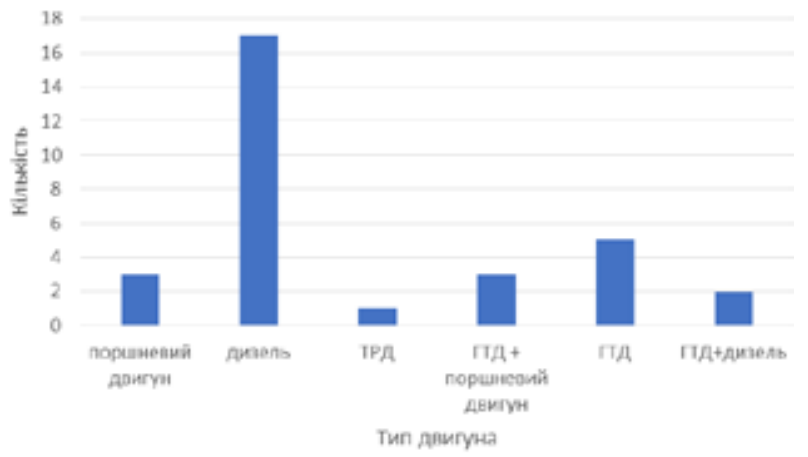

Рис. 9. Статистика застосування типів ЕУ

ДД за витратою палива мають перевагу перед ГТД, але суттєво поступаються за питомою вагою, тому якщо під час вибору типу ЕУ враховувати сумарну вагу установки з необхідним запасом палива на заданий запас ходу, що визначається тривалістю неперервного ходу на повній швидкості в годинах до повної витрати палива, то перевага виявляється на боці ГТД.

На рис. 10 наведено границі застосування двигунів різного типу для РАCSCAT [10].

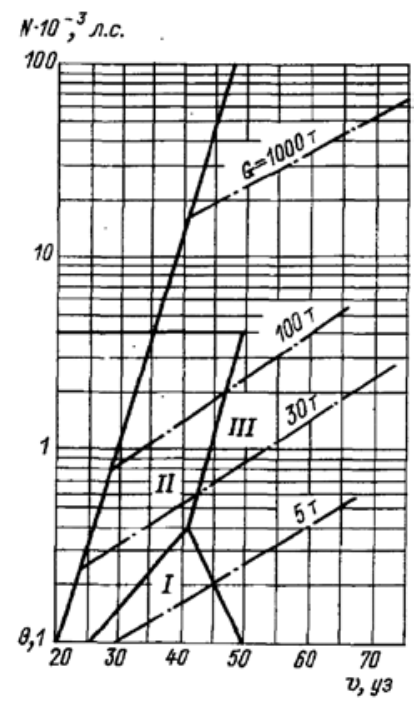

Рис. 10. Границі застосування двигунів різного типу: I - бензинові двигуни, II - легкі ДД, III - ГТУ.
Як головні двигуни ЕУ повного ходу РACSCAT, як правило, застосовують ГТД або конвертовані 3 віаційних турбореактивні двигуни (ТРД), однак для порівняно малих суден можуть використовуватись легкі дизелі.

Повітронагнітачі PACSCAT за аеродинамічною схемою, як правило, центробіжні, але інколи застосовують й осьові.

Як рушії можуть бути застосовані:

- широколопатні гребні гвинти регульованого кроку;

- суперкавітуючі гребні гвинти регульованого кроку;

- осьові водометні рушії.

Порівняння ККД рушіїв цих типів демонструє перевагу гребних гвинтів, однак зручність компонування водометних рушіїв у скегах у більшості випадків визначає їх більш широке застосування на PACSCAT (рис. 11).

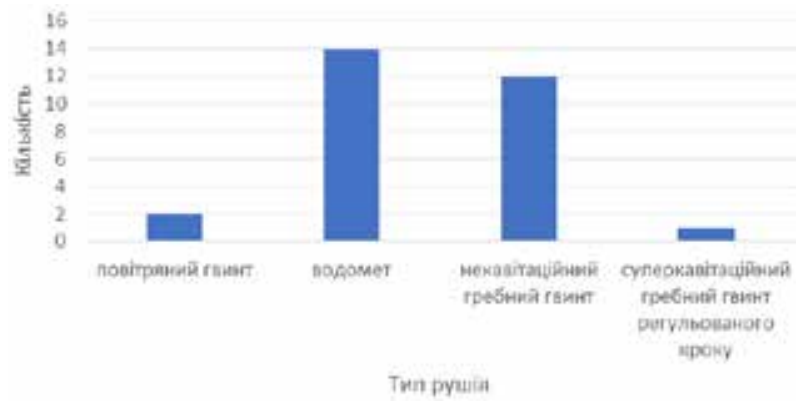

Рис. 11. Статистика застосування типів рушіїв

Загальна компоновка ЕУ PACSCAT здебільшого визначається особливостями форми й розмірів скегів. Водночас прийнятий під час проєктування тип рушіїв суттєво впливає на форму та розміри скегів. Як правило, ЕУ РАCSCAT складається із системи руху, що розділена побортно, та системи підтримання, яка розміщена в основному корпусі.

Підйомний комплекс та гнучке огородження

ПК PACSCAT (рис. 12) включає в себе елементи ЕУ (повітронагнітачі з привідними двигунами), корпусу (скеги) та специфічні елементи: повітроводи, ресивери, ГО області повітря підвищеного тиску, пристрою керування параметрами повітряних потоків (не обов'язково) [9], [10].

Основні параметри повітряного потоку - витрата повітря та середній статичний тиск у ПП - встановлюються у процесі відпрацювання гідравлічної схеми ПК під час проєктування PACSCAT. У гідравлічну схему, окрім повітронагнітачів, входять повітрозабірні пристрої, повітроводи, жорсткі та гнучкі ресивери, підкупольна частина, область витікання повітря підвищеного тиску в атмосферу.

Повітрозабірні пристрої виконують у вигляді отворів досить великої площі в палубі або стінках надбудови, розташованих поблизу від вхідних отворів 


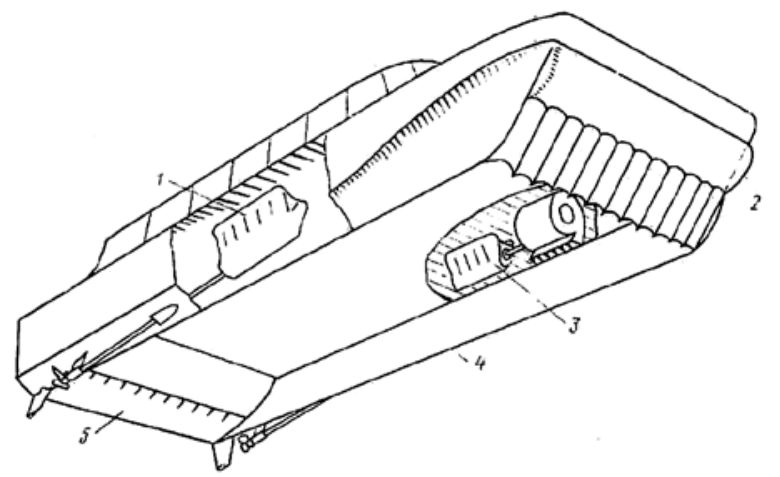

Рис. 12. Складники ПК та ЕУ: 1 - рушійний комплекс, 2 - носове ГО,3 - система нагнітання повітря, 4 - скег, 5 - кормове ГО.

повітронагнітачів та 3 урахуванням мінімізації потрапляння бризок води, які викликають ерозійне зношення лопаток нагнітачів. Від повітрозабірних отворів повітря або потрапляс до приміщення повітронагнітача й далі до його приймального отвору, або подається туди ж через спеціальний патрубок конфузор. Після повітронагнітача потік отримує значну швидкість, яка повинна бути перетворена в статичний тиск для уникнення значного зниження ККД ПК, для чого служать різного роду та конфігурації дифузори і повітроводи та ресивери, які поступово або різко розширюються.

Під час руху РACSCAT на хвилюванні внаслідок дії «хвильового поршня» об’єм і тиск в підкупольній частині можуть швидко та різко змінюватись, що призводить до такої ж зміни гідравлічного опору на виході повітря 3 нагнітача. У результаті в разі швидкого зростання тиску може навіть виникнути зворотний викид повітря через нагнітач. В альтернативному випадку внаслідок збільшення площі витікання 3-під кінцевих загороджень та скегів різко падає тиск у підкупольній частині, й задачею ПК $є$ відновлення тиску за час менше напівперіоду вертикальної хитавиці судна, щоб уникнути удару днищем о поверхню хвилі [9]. Водночас надлишкові витрати й тиск повітря, частково знижуючи опір руху PACSCAT на хвилюванні, суттєво збільшують вертикальні прискорення. 3 метою підвищення плавності руху на хвилюванні у ПК включають автоматичні пристрої керування, які дозволяють підтримувати близький до постійного тиск повітря в підкупольній частині [9].

Конструктивне виконання елементів ПК, особливо кінцевих ГО, може бути різноманітним. На рис. 13 наведено схему класифікації ПК за конструктивними особливостями ГО, типами аеродинамічних схем повітронагнітачів та типами приводів повітронагнітачів [9; 10].

ГО ПП РACSCAT представляс собою еластичну підднищову конструкцію, яка разом зі скегами служить для утворення замкненого по периметру днища простору, яке дозволяе обмежити витікання повітря та підтримувати статичний тиск повітря. Поділяється на носове та кормове ГО.

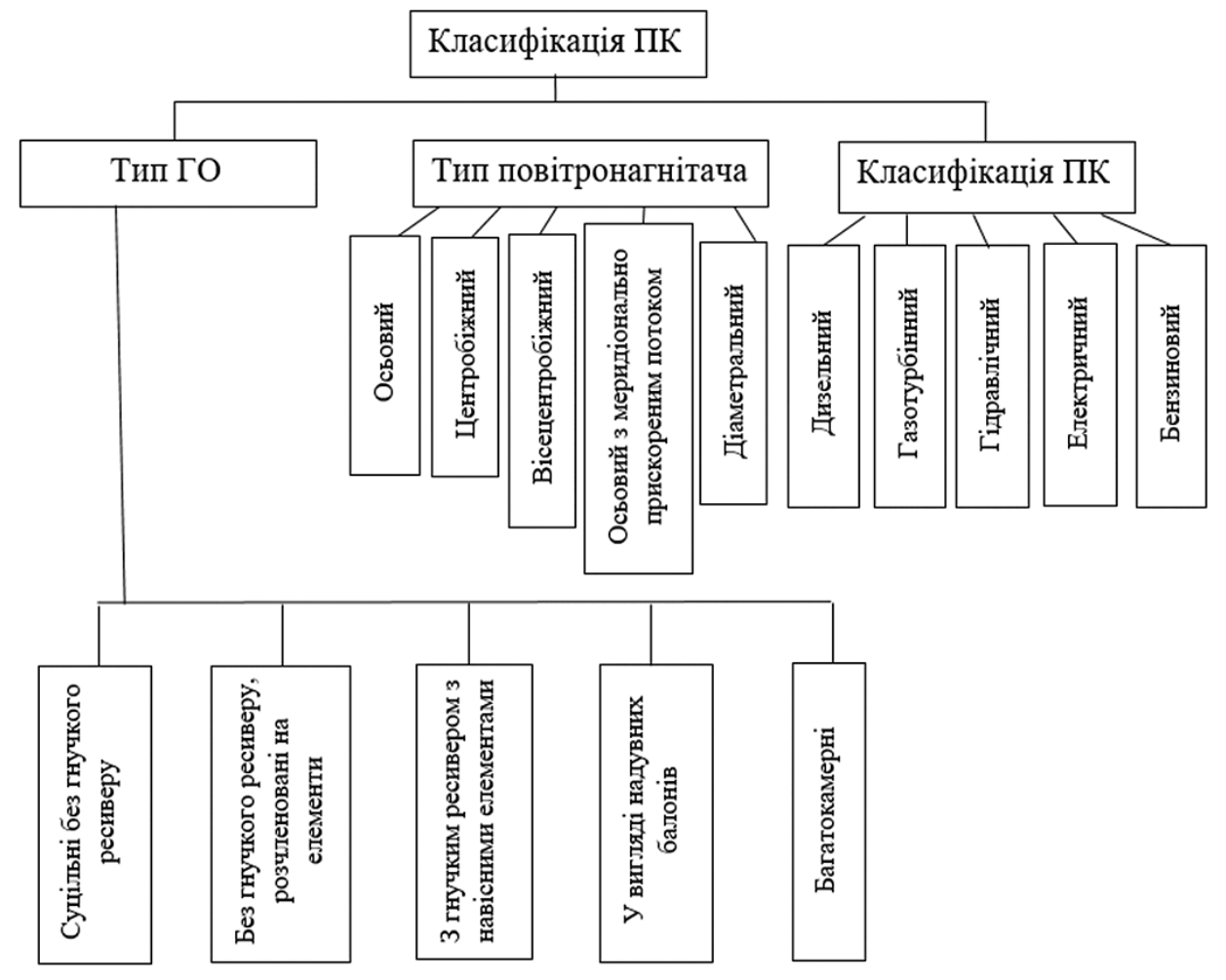

Рис. 13. Схема класифікації ПК 
Основними елементами ГО є:

- глісуючий жорсткий або напівжорсткий елемент, розташований у нижній частині огородження;

- гнучка надувна оболонка, що ущільнює основну частини простору між скегами - від глісуючого елементу до основного корпусу;

- гнучкі в'язі, що забезпечують зміну форми огородження, утримують від вивертання назовні під дією тиску ПП, а в ряді випадків забезпечують підтягування огородження до основного корпусу або його прибирання (в цьому варіанті повинне бути передбачено підйомно-опускний пристрій).

На рис. 14 зображено орієнтовний вигляд носового та кормового ГО.

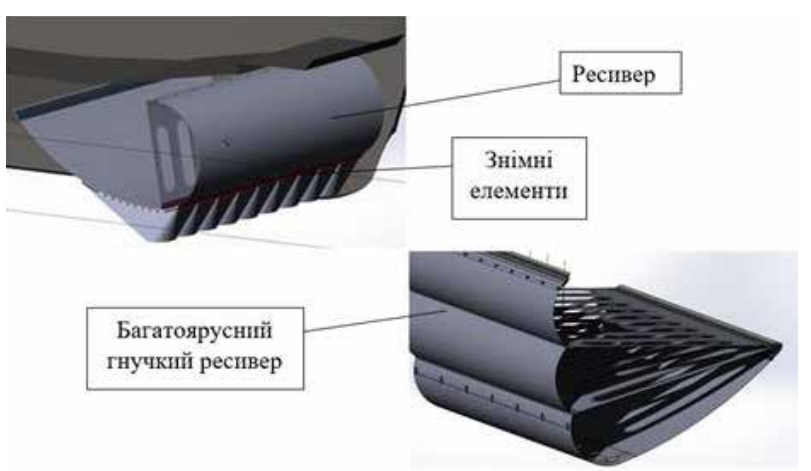

Рис. 14. Орієнтовний вигляд носового та кормового ГО

Натепер існує велика кількість патентів на винахід ГО різних типів, i, судячи по динаміці, ця тема буде мати розвиток і надалі.

\section{Недоліки та переваги PACSCAT}

Головним недоліком PACSCAT $є$ відносно висока ціна та вартість експлуатації. Це пов'язано $з$ досить складною конструкцією та вимогами дотримуватись вагової культури, як у авіації, хоча в порівнянні із суднами на ПП амфібійного типу ця вимога менш вагома.

Виготовлення кормового та носового загороджень ПП вимагає розроблення проєкту конструкції та самого еластичного матеріалу, але в Україні $\epsilon$ підприємства, які здатні з цим впоратись.

Основними перевагами РАCSCAT $\epsilon$ їхня швидкість та морехідність, а у порівнянні із суднами на ПП амфібійного типу - ще й висока прогнозована керованість, як у водотоннажного судна.

Оскільки PACSCAT - це катамаран, то він має всі переваги катамарану [21]: велика площа робочої палуби, гарна поперечна остійність, непотоплюваність, живучість, скритність. Завдяки високій швидкості та морехідності такий носій може забезпечувати успіх рятувальних операцій, надавати першу екстрену допомогу в рятуванні та евакуації людей до прибуття основних засобів допомоги, ефективно брати участь у підготуванні військових операцій та вогневій підтримці десанту.

Дворежимність руху (нерозвантажений та розвантажений режими) PACSCAT дозволяє на основі його платформи створювати кораблі протичовнового та протимінного призначення, які основним робочим режимом використовують докавітаційний тихий хід, а велика швидкість застосовується на терміновому переході в заданий район.

Можливості PACSCAT дозволяють їм мати велику ефективність у таких спеціальних системах, як протипожежна портова служба, коли необхідно поєднувати низьку швидкість та маневреність пожежного катера, необхідну під час проводження по акваторії порту суден з легкозаймистими вантажами, 3 можливістю розвивати високу швидкість та швидко прибувати в район раптової пожежі.

Обладнання в залежності від призначення корабля може замінюватись за модульним принципом.

\section{ВИСНОВКИ}

1. Особливості РACSCAT (відносно висока швидкість і морехідність, високий коефіцієнт утилізації маси за корисним навантаженням, можливість створення суден з великою вагою) можуть бути реалізовані лише за умови створення підсистем, які формують структуру судна та задовольняють вимогам, що до них висуваються. Так, не тільки корпус PACSCAT повинен мати форму та розміри, що забезпечать низький опір на тихій воді та хвилюванні, а й розміщені в ньому підсистеми повинні мати достатню міцність для руху на високих швидкостях на морському хвилюванні та мінімальні маси за досить високої надійності конструкції в експлуатації, енергетична установка також повинна бути легкою та потужною.

2. На основі корпусу та ЕУ, яка включає нагнітачі та рушійний комплекс, може створюватись платформа для цілого типоряду кораблів. Саме так переваги відпрацьованої скегової гідродинамічної схеми проявляться у вищій мірі. Висока швидкість навіть в умовах сильного хвилювання, стабілізація корпусу під час руху - ці якості дають величезну перевагу в плануванні та нанесенні ракетних ударів по цілях противника. Корабель може виходити скритно в район виконання завдання в режимі катамарану, а після нанесення удару переходити на високі швидкості для уникнення контрудару.

\section{REFERENCES}

[1] Jinglei Yang, Zhuang Lin, Zeyang Gao, Ping Li (2019) A Study on the Motion of Partial Air Cushion Support Catamaran in Regular Head Waves: Water.

[2] Molland A. F., Wilson P. A., Lewthwaite J. C., Taunton D. J. (2005) An investigation into the hydrodynamic characteristics of a high-speed PACSCAT: $8^{\text {th }}$ International Conference on Fast Sea Transportation. 


\section{СУДНОБУДУВАННЯ №3 2021}

[3] Zhiqun Guo, Hongde Qin, Q. W. Ma (2018) A study on hydrodynamics of the air cushion of a high-speed PACSCAT : City, University of London Institutional Repository.

[4] Jinglei Yang, Zhuang Lin, Ping Li, Zhiqun Guo, Hanbin Sun, Dongmai Yang (2020) Experimental investigation on the resistance performance of a high-speed PACSCAT: International Journal of Naval Architecture and Ocean Engineering.

[5] Guo Z. Q., Ma Q. W., Yang J. L. (2015) A seakeeping analysis method for a high-speed partial air cushion supported catamaran (PACSCAT): Ocean Eng. 110.

[6] Kochin V. A., Moroz V. V. (2013) Buksirovochnie issledovaniya modeli chastichno razgrugennogo s pomoshyu vozdushnoy podushki katamarana, kotoriy dvigetsya $\mathrm{v}$ kanale $\mathrm{v}$ diapazone kriticheskih skorostey: Visnik Odeskogo natcionalnogo morskogo Universitetu № 1(37). [in Russian]

[7] Sokolov V. P. (2005) Razrabotka metodiki proektirovaniya skorostnih mnogokorpusnih sudov, sochetayushih staticheskoe i dinamicheskoe podderganie: Sankt-Peterburgskiy Gosudarstvenniy Morskoy Tehnicheskiy Universitet. [in Russian]

[8] Arafmeev E.A.(2004)Eksperimentalnie i proektnie issledovaniya i razrabotka metodov opredeleniya ratcionalnih tehnicheskih parametrov visokoskorostnih sudov s dinamicheskimi printcipami podderganiya novih tipov: TcNII im. akad. A. N. Krilova. [in Russian]

[9] Smirnov S. A. (1983) Suda na vozdushnoy podushke skegovogo tipa: Leningrad, Sudostroenie. [in Russian]

[10] Kolizaev B. A., Kosorukov A. I., Litvinenko V. A. (1980) Spravochnik po proektirovaniyu sudov s dinamicheskimi printcipami podderganiya: Leningrad, Sudostroenie. [in Russian]

[11] ISO 12215-5:2019 Small craft - Hull construction and scantlings.

[12] Ejeleva L. «Legkie I neulovimie» (2016), jurnal «Morskoy biznes», № 44, www.mbsz.ru [in Russian]

[13] Grohovskiy A. «Sovremennoe plastikovoe sudostroenie», jurnal «Katera i yahti», № 217, www.yachtshipyard-wordpress.com. [in Russian]

[14] Dr. Leonidas Dokos (2013), «Adoption of marine composites a global perspective», mag. Reinforced Plastics.

[15] «Guide to composites», «Core materials», www.gurit.com.

[16] Nazarov A. G. (2013), «O stekloplastikovom sudostroenii i novom «tehnologicheskom rekorde», www.korabel.ru [in Russian]

[17] Beletckiy V. M., Krivov G. A. (2005) «Aluminievie splavi (Sostav, Svoystva, Tehnologiya), Spravochnik», Kiev. [in Russian]

[18] Kirilenko A. N. (2010) «Sudostroitelnie splavi na osnove aluminiya», jurnal «Spetcialna metallurgiya: vchora, sogodni, zavtra». [in Russian]

[19] Thomas Dorval, «Sail Aluminum» (About the use of different material in shipbuilding), BTS Aristide Briand High School, www.almet-marine.comennews-and-lme-quotation201451-news-2017115-sail-aluminium.html

[20] Korabli na vozdushnoy podushke skegovogo tipa: Voennoe obozrenie (2013), https://topwar.ru/24270-korablina-vozdushnoypodushke-skegovogo-tipa.html [in Russian]

[21] Dubrovskiy V. A. (2009) Mnogokorpusnie suda: nekotorie itogi razvitiya i novie tehnicheskie resheniya. Morehodstvo i morskie nauki. [in Russian]

\section{СПИСОК ВИКОРИСТАНОЇ ЛІТЕРАТУРИ}

[1] Jinglei Yang, Zhuang Lin, Zeyang Gao, Ping Li (2019) A Study on the Motion of Partial Air Cushion Support Catamaran in Regular Head Waves: Water.

[2] Molland A. F., Wilson P. A., Lewthwaite J. C., Taunton D. J. (2005) An investigation into the hydrodynamic characteristics of a high-speed PACSCAT: $8^{\text {th }}$ International Conference on Fast Sea Transportation.

[3] Zhiqun Guo, Hongde Qin, Ma Q. W. (2018) A study on hydrodynamics of the air cushion of a high-speed PACSCAT : City, University of London Institutional Repository.

[4] Jinglei Yang, Zhuang Lin, Ping Li, Zhiqun Guo, Hanbin Sun, Dongmai Yang (2020). Experimental investigation on the resistance performance of a high-speed PACSCAT: International Journal of Naval Architecture and Ocean Engineering.

[5] Guo Z. Q., Ma Q. W., Yang J. L. (2015). A seakeeping analysis method for a high-speed partial air cushion supported catamaran (PACSCAT): Ocean Eng. 110.

[6] Кочин В. А., Мороз В. В. (2013) Буксировочные исследования модели частично разгруженного с помощью воздушной подушки катамарана, который движется в канале в диапазоне критических скоростей. Вісник Одеського начіонального морського Університету. № (1)37.

[7] Соколов В. П. (2005) Разработка методики проектирования скоростных многокорпусных судов, сочетающих статическое и динамическое поддержание. Санкт-Петербургский Государственный Морской Технический Университет.

[8] Арафмеев Э. А. (2004) Экспериментальные и проектные исследования и разработка методов определения рациональных технических параметров высокоскоростных судов с динамическими принципами поддержания новых типов: ЦНИИ им.акад. А. Н. Крылова.

[9] Смирнов С. А. (1983) Суда на воздушной подушке скегового типа. Ленинград, Судостроение.

[10] Колызаев Б. А., Косоруков А. И., Литвиненко В. А. (1980). Справочник по проектированию судов с динамическими принципами поддержания: Ленинград, Судостроение. 
[11] ISO 12215-5:2019 Small craft - Hull construction and scantlings.

[12] Ежелева Л. «Легкие и неуловимые» (2016) «Морской бизнес». № 44. URL: www.mbsz.ru

[13] Гроховский А. «Современное пластиковое судостроение». «Катера и яхты». № 217. URL: www.yachtshipyard-wordpress.com

[14] Dr. Leonidas Dokos (2013) «Adoption of marine composites a global perspective», mag. Reinforced Plastics.

[15] «Guide to composites», «Core materials». URL: www.gurit.com

[16] Назаров А. Г. (2013) «О стеклопластиковом судостроении и новом «технологическом рекорде». URL: www.korabel.ru

[17] Белецкий В. М., Кривов, Г. А. (2005) «Алюминиевые сплавы (Состав, Свойства, Технология). Справочник». Киев.

[18] Кириленко А. Н. (2010) «Судостроительные сплавы на основе алюминия». «Спеціальна металлургія: вчора, сьогодні, завтра».

[19] Thomas Dorval. «Sail Aluminum» (About the use of different material in shipbuilding), BTS Aristide Briand High School. URL: www.almet-marine.comennews-and-lme-quotation201451-news-2017115-sail-aluminium.html

[20] Корабли на воздушной подушке скегового типа. Военное обозрение. (2013). URL: https:/topwar.ru/ 24270-korablina-vozdushnoy-podushke-skegovogo-tipa.html

[21] Дубровский В. А. (2009) Многокорпусные суда: некоторые итоги развития и новые технические решения. Мореходство и морские науки.

С Томашевська Т. В

Дата надходження статті до редакції: 27.07.2021

Дата затвердження статті до друку: 10.08.2021 